\title{
POWDERY LEAF EXTRACTS FOR CONTROL OF ROOT KNOT NEMATODE IN AFRICAN YAM BEAN
}

\author{
K.I. UGWUOKE, B.O. UKWUEZE and S.I. OGWULUMBA ${ }^{1}$ \\ Department of Crop Science, University of Nigeria, Nsukka,Nigeria \\ ${ }^{1}$ Department of Crop Production Technology, Federal College of Agriculture Ishiagu, Nigeria \\ Correspondence author: sitwithsolo@yahoo.com
}

(Received 15 June, 2010; accepted 29 May, 2011)

\begin{abstract}
Synthetic chemicals have been used to control plant pathogenic nematodes in the farmers fields. These chemicals, though valued for their effectiveness, are costly and may constitute health hazards to farm households and the environment. Reducing these situations in the farms through use of natural plant extracts is one of the challenges in Nigeria. Powdery extracts of Jatropha curcas, Parkia biglobosas, Newbouldia laevis, Ficus exasperata and Cassia alata were evaluated for the control of M. incognita in yam bean (Sphenostylis stenocarpa Hochst ex A. Rich) at the University of Nigeria, Nsukka in Nigeria. Newbouldia laevis extract significantly $(\mathrm{P}<0.05)$ controlled the galling of Meloidogyne incognita, while the efficacy of other extracts were insignificant $(\mathrm{P}>0.05)$. Newbouldia laevis extract had significant effects on the height of the plant. Significant difference was observed on the plants height. Newbouldia laevis extract reduced the number of galls from 1.89 to 1.18 and increased the height from 106.1 to $213.3 \mathrm{~cm}$ and the number of leaves from 59.2 to 69.2 compared with control (water treatment). Cassia alata extract had a significant effect on both leaf numbers and stem height of the plant. It increased the number of the leaves from 59.2 to 81.3 and the height from 196.1 to $201.3 \mathrm{~cm}$, and the number of root gall from 1.89 to 2.49.
\end{abstract}

Key Words: Jatropha curcas, Newbouldia laevis, Meloidogyne incognita

\section{RÉSUMÉ}

Les produits chimiques synthétiques ont été utilisés pour le contrôle des nématodes pathogéniques des plantes dans les champs des fermiers. Même si ces produits sont reconnus pour leur efficacité, ils sont coûteux et pourraient aussi causer des dommages aux champs des fermiers et à l'environnement. La réduction de ces situations non profitables par l'utilisation des extraits naturels de plantes est l'un des défis au Nigeria. Des extraits en poudre de Jatropha curcas, Parkia biglobosas, Newbouldia laevis, Ficus exasperata et Cassia alata étaient évalués pour le contrôle de M. incognita dans des ignames (Sphenostylis stenocarpa Hochst ex A. Rich) à l'Université de Nigeria à Nsukka au Nigeria. L'extrait de Newbouldia laevis avait significativement $(\mathrm{P}<0.05)$ contrôlé l'apparition des gales de Meloidogyne incognita, alors que d'autres extraits n'ont présenté aucun effet significatif $(\mathrm{P}>0.05)$. L'effet de l'extrait de Newbouldia laevis était significativement observés au niveau de la hauteur des plants. Le traitement avec extrait de Newbouldia laevis avait réduit le nombre de gales de 1.89 à 1.18 et augmenté la hauteur des plants de 106.1 à $213.3 \mathrm{~cm}$ et le nombre de feuilles de 59.2 à 69.2 par rapport au témoin traité avec l'eau. L'extrait de Cassia alata avait un effet significatif sur le nombre de feuilles et la hauteur des tiges. Ce dernier avait induit l'augmentation du nombre de feuilles de 59.2 à 81.3 et la hauteur des plants de 196.1 to $201.3 \mathrm{~cm}$ ainsi que l'augmentation du nombre de gales racinaires de 1.89 à 2.49 .

Mots Clés: Jatropha curcas, Newbouldia laevis, Meloidogyne incognita 


\section{INTRODUCTION}

African yam bean (Sphenostylis stenocarpa Hochst ex A. Rich) is a herbaceous leguminous plant growing throughout tropical Africa. It is an annual crop belonging to the family leguminosae (IITA, 2010). Among the many pests that affect grain legumes, particularly Africa yam bean production are plant parasitic nematodes (Muthukrishnan et al., 2003). Meloidogyne incognita causes severe yield losses, typically up to 50 percent. This is mainly as a result of root deformation which diminishes their function and predisposes plants to pathogens. It affects crops directly and indirectly by their interaction with various soil borne fungi, bacteria and viruses (Udo et al., 2008).

The most predominant species of root knot nematodes are Meloidogyne incognita, $M$. javanica, $M$. arenaria and M. Hapla. Meloidogyne spp. are notoriously difficult to control because of their wide host range and high rates of reproduction. They possess generation times of typically between 20 and 30 days in tropical soils and females are capable of producing a thousand eggs ( Udo et al., 2008). However, in order to meet the consumption needs of African yam bean, the health of the crop must be considered. Many synthetic nematicides are expensive and highly toxic (Ploeg, 2002; Wang et al., 2002).

In recent years, there has been considerable interest in the nematostatic properties of African medicinal plants, but reports on the effect of botanical extract on root knot nematodes and plant growth are still limited or lacking.

The aim of this work was to determine the effectiveness of extracts from Jatropha curcas, Parkia biglobosa, Newbouldia laevis, and Cassia alata on the root knot nematodes of African yam bean.

\section{MATERIALS AND METHODS}

The study was conducted in a greenhouse of Department of Crop Science, University of Nigeria, Nsukka in Nigeria in 2009 and repeated in 2010 .
Plant materials. The plants used were Jatropha curcas, Parkia biglobosa, Newbouldia laevis, Ficus exasperata and Cassia alata. These plants were collected in the Province of Nsukka in Nigeria. The plants were obtained locally from their wild growing stands.

The seed sample of African yam bean (Sphenostylis stenocarpa Hachest ex.A.Rich) was obtained from Orie Orba main market, in Ude-Enu Local Government Area, Enugu State in Nigeria.

The root knot nematode (M. incognita) inoculum was obtained from the pots of preserved nematode growing culture in the Crop Protection Unit, Department of Crop Science, University of Nigeria, Nsukka.

Preparation of powdery extracts. Fresh older leaves of the test plants were collected and identified botanically at the Department of Botany, Faculty of Biological Science, University of Nigeria, Nsukka. They were then sun-dried separately for five days. The drying was timed for nine hours daily. Each of the samples was then ground to powder using Thomas Wiley laboratory grinding machine. It was then sieved through $0.02 \mathrm{~mm}$ diameter sieve.

Preparation of nematode inoculum. The roots of African yam bean growing in nematode pots culture ( $M$. incognita) with pronounced galls were harvested and crushed with a blender machine. One hundred millilitres of distilled water was put into the blender and the galled roots blended into slurry. The blending was run for three seconds only at each interval and for three intervals to prevent the slurry from getting hot and inactivate the nematode larvae. The slurry was made up to $300 \mathrm{ml}$ by adding more water. Thirty millilitres of the mixture were poured into a counting dish in which the number of larvae was approximately $100030 \mathrm{ml}^{-1}$. The slurry was prepared each day of inoculation for immediate use.

Pot experiment. The experiment was laid out as $4 \times 5$ factorial in completely randomised design (CRD), replicated three times. Each replicate consisted of nine sampling pots. 
Terracotta plant-pots $(30 \mathrm{~cm}$ diameter, $30 \mathrm{~cm}$ height) in the above layout were half filled with the soil mixture. African yam bean seeds were sown in each pot at the rate of three seeds per hole and the seedlings were later thinned down to one two weeks after germination.

The pots were watered once daily. The seedlings were inoculated with nematodes at two growth stages ( 3 and 11weeks after planting). The gall slurry was used as the standard inoculum at the rate of $30 \mathrm{ml}$ per pot, equivalent to 1000 larvae of nematode ( $M$. incognita) in each pot, except the control pots. It was poured evenly around the stem of each seedling. The stage one pots were treated with the powdery extracts by sprinkling it over the soil around the plant stemsoil contact points, raked in and watered into the soil three weeks after inoculation at the rate of $12 \mathrm{~g}$ per pot. The same was done to the second stage pots at three weeks of inoculation. Observations were recorded on plant height, number of leaves and branches 15 weeks after planting, while stem weight and number of galls in the roots were recorded 24 weeks after planting.

Efficacy of extracts on the root knot nematode. The total number of nematode galls was counted per root irrespective of size and root infestation, and graded from 0 to $5(0=$ no galls, $1=1-2$ galls; $2=3-10$ galls, $3=11-30$ galls, $4=31-100$ galls, and $5=>100$ galls).

Statistical analysis. The data collected were statistically analysed by analysis of variance
(ANOVA) and significant differences in means were ranked using least significant difference (LSD) test (GenStat software). Nematode infestation data were similarly analysed after square-root transformation (Gomez and Gomez, 1984).

\section{RESULTS}

Efficacy of extracts. The efficacy of botanical powdery extracts on $M$. incognita of African yam bean is shown on Table 1. Newbouldia laevis extract had the least number of galls in both stages of inoculation (1.18). This differed significantly $(\mathrm{P}<0.05)$ from that of Casia alata, which recorded the highest number of galls in the two stages of inoculations (2.49). Other extracts were not significant $(\mathrm{P}>0.05)$.

Stage one inoculation also gave the least number of galls (1.13). It differed significantly $(\mathrm{P}<0.05)$ from that of stage two inoculation, which recorded a high number of galls (6.33). Newbouldia laevis at stage one of inoculation gave the least number of galls $(0.00)$ and differed significantly from Casia alata, which gave highest number of galls (7.61) at stage two. The activity of the extracts decreased with prolonged time of inoculation.

\section{Growth and development of yam bean.} Newbouldia laevis recorded the highest mean height $(213.3 \mathrm{~cm})$ and differed significantly from that of water (control), which gave the lowest mean height $(196.1 \mathrm{~cm})$ (Table 2). Plant height in other extracts also differed

TABLE 1. Effect of Botanical Extracts on the number of galls of African yam bean plant

\begin{tabular}{lcccccc}
\hline Inoculations & \multicolumn{5}{c}{ Botanical extracts } & Mean \\
\cline { 2 - 6 } & Cassia & Jatropha & Newbouldia & Parkia & Water \\
\hline Inoc Time 1 & 2.33 & 1.00 & 0.00 & 2.00 & 0.33 & 1.13 \\
Inoc Time 2 & 7.61 & 6.00 & 4.72 & 6.11 & 7.22 & 6.33 \\
Uninoc Time 1 & 0.00 & 0.00 & 0.00 & 0.00 & 0.00 & 0.00 \\
Uninoc Time 2 & 0.00 & 0.00 & 0.00 & 0.00 & 0.00 & 0.00 \\
Mean & 2.49 & 1.75 & 1.18 & 2.03 & 1.89 & \\
\hline & & & & & \\
LSD $_{0.05}$ for comparing any two inoculation means & & & & $=1.043$ \\
LSD $_{0.05}$ for comparing any two extract means & & & & $=1.166$ \\
LSD $_{0.05}$ for comparing inoculation and extract interaction &
\end{tabular}


significantly. Stages of inoculation had no significant $(\mathrm{P}>0.05)$ effect on the height of the plant. The interaction of nematode inoculation and extracts showed that Parkia biglobosa extract at stage one of inoculation led to the highest height $(220.9 \mathrm{~cm})$ and least at stage two $(210.1 \mathrm{~cm})$, but did not differ significantly $(\mathrm{P}>0.05)$.

The effect of extracts on plant leaf number is shown in Table 3. It is clear that $C$. alata gave the highest number of leaves (81.3) and differed significantly $(\mathrm{P}<0.05)$ from that of $P$. biglobosa, which recorded the least value. Nematode inoculation stage had no significant $(P>0.05)$ effect on the number of leaves of the yam bean. The two stages differed significantly $(\mathrm{P}<0.05)$ for uninoculated plants. The uninoculated stage one (early stage) recorded the highest number of leaves (78.7).

The interaction of $J$. curcas and nematode inoculation at stages one (95.2) and two (54.4) differed significantly $(\mathrm{P}<0.05)$.

Table 4 shows the effect of extracts on the stem weight. Casia alata gave the highest weight $(22.6 \mathrm{~g})$ which was significantly different $(\mathrm{P}<0.05)$ from that of P. biglobosa $(14.85 \mathrm{~g})$. Stages of nematode inoculation had no significant $(\mathrm{P}>0.05)$ effect on the stem weight of the plant; while stages of growth significantly affected stem weight of uninoculated plants The stage two un-inoculation (later stage) gave the highest stem weight $(21.08 \mathrm{~g})$, while that of stage one (early stage) recorded the least value $(23.58 \mathrm{~g})$.

TABLE 2. Effect of botanical extracts and nematode on the height of African yam bean plant

\begin{tabular}{|c|c|c|c|c|c|c|}
\hline \multirow[t]{2}{*}{ Inoculations } & \multicolumn{5}{|c|}{ Botanical extracts } & \multirow[t]{2}{*}{ Mean } \\
\hline & Cassia & Jatropha & Newbouldia & Parkia & Water & \\
\hline Inoc Time 1 & 215.6 & 213.3 & 213.9 & 220.9 & 196.3 & 212.3 \\
\hline Inoc Time 2 & 207.3 & 212.4 & 220.4 & 210.1 & 203.0 & 210.6 \\
\hline Uninoc Time 1 & 204.3 & 213.0 & 216.7 & 210.0 & 193.3 & 201.5 \\
\hline Uninoc Time 2 & 214.7 & 201.0 & 202.0 & 163.7 & 192.0 & 194.7 \\
\hline Mean & 201.5 & 209.9 & 213.3 & 201.2 & 196.1 & \\
\hline $\begin{array}{l}\mathrm{LSD}_{0.05} \text { for comp } \\
\mathrm{LSD}_{0.05} \text { for comp } \\
\mathrm{LSD}_{0.05} \text { for inocu }\end{array}$ & $\begin{array}{l}\text { any two } \\
\text { any two } \\
\text { and ex }\end{array}$ & $\begin{array}{l}\text { atode inocu } \\
\text { ct means } \\
\text { interaction }\end{array}$ & & & & $\begin{array}{l}=10.23 \\
=11.44 \\
=22.87\end{array}$ \\
\hline
\end{tabular}

TABLE 3. Effect of botanical extracts and nematode on the number of leaves of African yam bean

\begin{tabular}{lllllll}
\hline Inoculations & \multicolumn{5}{c}{ Botanical extracts } & Mean \\
\cline { 2 - 5 } & Cassia & Jatropha & Newbouldia & Parkia & Water \\
\hline Inoc Time 1 & 87.7 & 95.2 & 85.0 & 12.6 & 54.9 & 67.1 \\
Inoc Time 2 & 77.26 & 54.4 & 65.3 & 67.1 & 64.8 & 64.8 \\
Uninoc Time 1 & 83.7 & 71.3 & 84.7 & 89.3 & 64.3 & 78.7 \\
Uninoc Time 2 & 81.3 & 44.0 & 42.0 & 42.3 & 52.7 & 52.3 \\
Mean & & & & & \\
\hline & & & & & \\
LSD $_{0.05}$ for comparing any two nematode inoculation means & & & \\
LSD $_{0.05}$ for comparing any two extracts means & & & \\
LSD $_{0.05}$ for inoculation and extracts interaction &
\end{tabular}


TABLE 4. Effect of botanical extracts and nematode on the stem weight $(\mathrm{g})$ of African yam bean

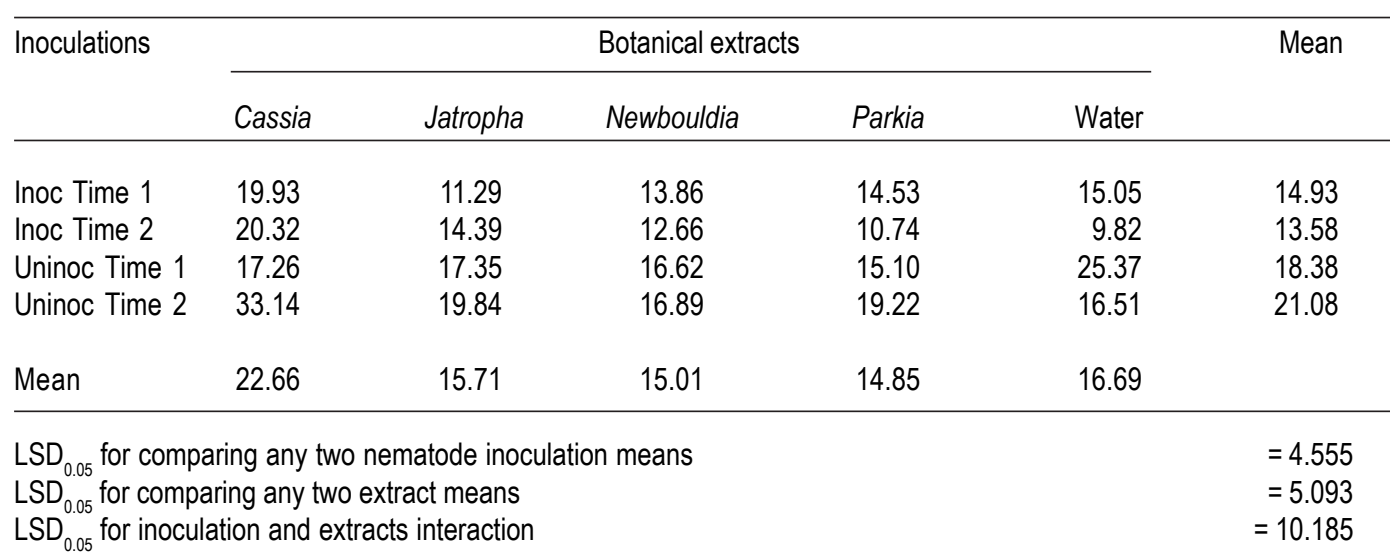

\section{DISCUSSION}

Results have shown that there is a general reduction in nematode (Meloidogyne incognita) infestation of African yam bean upon application of powdery extracts in both stages of inoculation. Stage one significantly $(\mathrm{P}<0.05)$ reduced $M$. incognita gall formation in the root of the bean, contrasting with stage two inoculation. This observed significant reduction of $M$. incognita gall in stage one inoculation against stage two could be attributed to the relative root development in the plant prior to nematode introduction. In stage one, tender and relatively little roots developed compared to the tougher and more roots developed in the stage two. Consequent upon that, at stage one inoculation, the nematode population was controllable and the extra depressed the nematode activities. At stage two inoculation, there was a relatively high juvenile of $M$. incognita population and as such reduced the efficacy of the powdery extracts.

Newbouldia. laevis plant extracts significantly suppressed $M$. incognita gall formation on roots (Table 1). Nematicidal activity of N.laevis in this study was in line with the work of Kuete et al. (2007) and Eyong et al. (2006) where the leaf extract was reported to have antimicrobial property.

Plant growth parameters were significantly improved over the infested check and were comparable with those obtained from plants grown in infested soil treated with leaf extracts
(Table 2). The powdery extracts of N. leavis was significant on height of African yam bean plant when compare with the control $(\mathrm{P}<0.05)$. This was attributed to the high nematicidal efficacy of the extract. It follows the assumption that when a plant is growing under pest free and adequate nutrients environment, it grows faster. The finding is justified in the (Natarajan et al., 2006) work where extract of Tagetes erecta boosted the height of tomatoes growing on nematode infected soil. Powdery extract of P.biglobosa was significant on height of African yam bean plant at stage one inoculation when compared with stage two inoculation. This proves the significance of the interaction of nematode and extracts $(\mathrm{P}<0.05)$. This was due to the higher population of $M$. incognita.

Though $C$. alata extract had insignificant nematicidal potency, it prevented the infection of other microbes and supply the growing plants with carbohydrate (essential macronutrient) for maximum growth and proper respiration. Consequent to these, the finding was justified.

\section{REFERENCES}

Embaby, E.M. and Abdel-Galil, M.M. 2006. Seed borne fungi and mycotoxins associated with some legume seeds in egypt. Journal of Applied Sciences Research 2(11):10641071.

Eyong, K.O., Folefoc, G.N., Kuete, V. Beny, V.P., Krohn, K. Hussain, H., Nkengfack, A.E., Saeffel, M, Sarite, S.R. and Hoerauf, A. 2006. 
Newbouldiaquinone A: A naphthoquinoneanthraquinone ether coupled pigment, as a potential antimicrobial and antimalarial agent from newbouldia laevis. Phytochemisty 67: 605-609.

Gomez, K.A. and Gomez, A.A. 1984. Statistical Procedures for Agricultural Research, Wiley, New York. USA. 680p.

Kuete, V., Eyong, K.O., Folefoc, G.N., Beny, V.P., Hussain, H., Krohn, K. and Nkengfack, A.E. 2007. Antimicrobial activity of the methanolic extract and the Chemical Constituents Isolated from Newbouldia Leavis Pharmazie 62(7):552-556.

Muthukrishnan, N., Ganapathy, N., Nalini, R. and Rajendran, R. 2003. Pests of tomato, Pest Management in Horticultural Crops, New Madurai Publishers, India. pp. 123-134.

Natarajan, N., Cork, A., Boomathi, N., Pandi, R., Velavan, A.S. and Dhakshnamoorthy, G. 2006. Cold aqueous extracts of African marigold, Tagetes erecta for control tomato root knot nematode, Meloidogyne incognita. Natural Resources Institute Press, United Kindom. Nwachukwu, E.O. and Umechuruba, O.I. 2001. Antifungal activities of some leaf extracts on seed-borned fungi of African yam bean seeds, seed germination and seedling emergence. Journal Applied Science and Management 5:24-32.

Ploeg, A.T. 2002. Effects of selected marigold varieties on root-knot nematodes and tomato and melon yields. Plant Disease 86:505508.

Ugwuoke, K.I. and Ukwueze, B.O. 2010. Efficacy of Some Leaf Extracts on Some Seed Borne Fungi of African Yam Bean (Sphenostylis Stenocarpa Hochest Ex.A.Rich). Not published, Available in Crop Science Department library, University of Nigeria Nsukka, Nigeria.

Wang, K.H., Sipes, B.S. and Schmitt, D.P. 2002. Management of Rotylenchulus reniformis in pineapple, Ananas comosus, by intercycle cover crops. Journal of Nematology 34:106-114. 